\title{
Future and Sustainable Development of Applied Mineralogy
}

\author{
Faqin Dong ${ }^{1}$
}

Published online: 27 March 2015

(C) Springer-Verlag Wien 2015

This special issue is one part of the post-conference publications of the 11th International Congress for Applied Mineralogy (ICAM), held at Southwest University of Science and Technology (SWUST) in Mianyang, China, on 05-10 July 2013.

The biennial International Congress for Applied Mineralogy (ICAM) is the most important gathering of applied mineralogists, organized every odd year by the ICAM council. The field of Applied Mineralogy responds to the ever increasing demands from society. Thirty-two years after the inception of the first ICAM in Johannesburg, South Africa in 1981, Applied Mineralogy is more than ever before a hot topic.

The field of Applied Mineralogy has been able to match society's pace by continuously reinventing itself, quickly adopting new technologies and instrumentation as they became available, and put them to work at the service of mankind living in a world substantially relying on minerals. Over the past decennia, Applied Mineralogy has evolved into a trend-setting discipline, staking out course for science and engineering, research and development, for the benefit of society. Contrary to popular layman belief, mineral resources are limited, and we are obliged to our heirs to use them responsibly.

In a bidding competition during the 10th ICAM in Trondheim/Norway in 2011, China won the votes to host the 11th ICAM in 2013. Today China is a country in blazing development, with numerous mineral resources and a scientific proliferation to match. The 11th ICAM in Mianyang of China is another important international mineral congress that was held in China in the last 15 years since the 15th IMA and 15th world mining congress at Beijing in 1990, and 30th IGC 1996.

Professor Faqin Dong is an Editor-in-Chief of 11th ICAM and President ICAM Council

Prof. Faqin Dong

2013-icam@vip.163.com

1 Mianyang, China
With the development of productive forces, human exploitation of natural resources has been improved a lot. Sustainable development is the only way to ease the expanding intense relationship between human and nature as well as to solve the problems between increasing demands for resources and environment. Therefore, the topic of the 11th ICAM was "Future and Sustainable Development of Applied Mineralogy". Under this theme, 9 sections were designed, including Environmental and Medical Mineralogy, Industrial Minerals, Gemology, Biominerals and Biomaterials, Advanced Materials, Process Mineralogy, Mining and Metallurgy, Cultural Heritage, Interaction of Minerals with Microorganisms, Solid Waste Treatment and Recycling, and Genetic Mineralogy.

Also, the 11th ICAM congress aimed at further strengthening worldwide academic exchange and cooperation in Applied Mineralogy, and offering a platform for scientists and engineers to discuss recent research progress with a focus on future trends on applied mineralogy and promote interdisciplinary cooperation.

Between 5-10 July 2013, over 200 delegates from 18 countries attended to the congress. At the conference, 7 keynote lectures, 122 oral contributions and 22 posters were presented. 146 abstracts and 68 full papers were submitted to the conference. Abstracts have been published in Acta Mineralogical Sinica in July 2013. The post-conference publications consist of two parts, including this special issue and electronic proceedings both published by Springer. Out of 60 selected contributions, 15 papers were submitted to Mineralogy and Petrology, and nine papers have been finally accepted after going through the peer reviewing process. These nine selected papers published in this special issue reflect the wide spectrum of topics presented at the conference.

In the section on Process Mineralogy, Mining and Metallurgy, J. Zhang et al. present a paper on the flotation characteristics of native ilmenite, which were investigated by a series of analytical methods. LH Xu et al. present a paper on the effects of particle size and chain length on flotation of quaternary ammonium salts (QAS) onto kaolinite by mico-flotation tests.

Papers from the Industrial Minerals, Minerals Structure and Surface section include: XH Zhang et al.'s contribution on the 
thermal decompositions of Ca-bentonites from Santai, Shichuan Province, China. Bentonites were studied over the temperature range of $30-1100{ }^{\circ} \mathrm{C}$ by simultaneous thermal analyzer. P. Ferreira Barbosa's paper deals with different microstructures related to the phase transformation of natural and synthetic magnetite to hematite. The paper by ZY Wang et al. deals with the genesis and formation conditions of Hercynian fluorite deposits in the Central Uplift zone of the Tarim Basin.

A paper selected from the Advanced Materials symposium is by JX Zhu et al. who used sulphobetaine and montmorillonites to synthesize a novel type of organo-clays, i.e., zwitterionic surfactant modified montmorillonites (ZSMMs), which can be used for wastewater treatment and effectively remove organic contaminants with both negative and positive charges.

Three papers fall into the field of Environmental and Medical Mineralogy: F. Meng et al. investigated psammoma bodies (PBs) in human tissues. The detailed mineralogical characterization may help to uncover the nature of pathological PBs in ovaries. The L. Zhang et al. paper reports results of experiments on the dissolution of different types of natural dusts interacting with amino acids solution. Finally, W. Chen et al. present data on the mineralogy and surface zeta potential of atmospheric dust fall in NW China.

These are fascinating times for research in applied mineralogy with multiple and diverse opportunities being offered by emerging analytical techniques and novel instrumentation allowing us to authenticate all-new insights, or to critically re-assess established verities. However, as scientists we must remain aware of the interim character of the knowledge we have garnered: whereas some findings have stood "forever", others have turned obsolete before long. The latter should not make us sad: new ground has been broken, new uncharted areas lay galore to be explored. 